\title{
THE EFFECTS OF SOCIAL ECONOMIC FACTORS ON DIARRHEA IN DEMAK, CENTRAL JAVA
}

\author{
Aulia Noorvita Ramadani'), Sri Rahardjo²), Bhisma Murti²) \\ 1) Masters Program in Public Health, Universitas Sebelas Maret \\ 2)Faculty of Medicine, Universitas Sebelas Maret
}

\begin{abstract}
Bckground: Diarrhea is a public health problem with high mortality and morbidity. Diarrhea can be prevented by maintaining cleanliness and a healthy lifestyle. This study aimed to determine the effect of socioeconomic factor on the incidence of diarrhea.

Subjects and Method: A case control study was conducted in Demak, Central Java, from October to November 2018. A sample of 200 study subjects was selected by fixed disease sampling. The dependent variable was diarrhea. The independent variables were education, had washing using soap, family income, clean water availability, latrine availability, water waste management, and waste management. The data were collected by questionnaire and analyzed by a multiple logistic regression.

Results: Risk of diarrhea increased with poor clean water availability $(\mathrm{OR}=4.06 ; 95 \%$ $\mathrm{CI}=1.34$ to $12.3 ; \mathrm{p}=0.013)$, poor latrine availability $(\mathrm{OR}=6.33 ; 95 \% \mathrm{CI}=2.02$ to 19.8 ; $\mathrm{p}=0.002)$, poor water waste management $(\mathrm{OR}=14.2 ; 95 \% \mathrm{CI}=4.77$ to $42.7 ; \mathrm{p}<0.001)$, poor waste management $(\mathrm{OR}=3.74 ; 95 \% \mathrm{CI}=1.24$ to $11.2 ; \mathrm{p}=0.019)$, and didn't wash hands using soap ( $\mathrm{OR}=3.39 ; 95 \% \mathrm{CI}=1.18$ to $9.74 ; \mathrm{p}=0.023)$. Risk of diarrhea decreased with high family income $(\mathrm{OR}=0.24 ; 95 \% \mathrm{CI}=0.08$ to $0.69 ; \mathrm{p}=0.008)$ and high education $(\mathrm{OR}=0.18 ; 95 \% \mathrm{CI}=0.06$ to $0.56 ; \mathrm{p}=0.003)$.

Conclusion: Risk of diarrhea increases with poor clean water availability, poor latrine availability, poor water waste management, poor waste management, and didn't wash hands using soap. It decreases with high family income and high education.
\end{abstract}

Keywords: diarrhea, social economic factors, hand wash behavior

\section{Correspondence:}

Aulia Noorvita Ramadani. Master Program in Public Health, Universitas Sebelas Maret. Jl. Ir. Sutami 36 A, Surakarta 57126, Central Java, Indonesia. Email: aulia.noorvita@yahoo.com. Mobile: +6285641577322

The $5^{\text {th }}$ International Conference on Public Health Best Western Premier Hotel, Solo, Indonesia, February 13-14, 2019 | 61 https://doi.org/10.26911/theicph.2019.01.07 